\title{
Clinical characteristics of patients with cerebellar ataxia associated with anti-GAD antibodies
}

\author{
Características clínicas de pacientes com ataxia cerebelar associada a anticorpos anti-GAD \\ Tiago Silva Aguiar ${ }^{1}$, Andrea Fragoso², Carolina Rouanet de Albuquerque1, Patrícia de Fátima Teixeira², \\ Marcus Vinícius Leitão de Souza ${ }^{3}$, Lenita Zajdenverg², Soniza Vieira Alves-Leon ${ }^{1,4}$, Melanie Rodacki², \\ Marco Antônio Sales Dantas de Lima
}

\begin{abstract}
The enzyme glutamic acid decarboxylase (GAD), present in GABAergic neurons and in pancreatic beta cells, catalyzes the conversion of gamma-aminobutyric acid (GABA). The cerebellum is highly susceptible to immune-mediated mechanisms, with the potentially treatable autoimmune cerebellar ataxia associated with the GAD antibody (CA-GAD-ab) being a rare, albeit increasingly detected condition. Few cases of CA-GAD-ab have been described. Methods: This retrospective and descriptive study evaluated the clinical characteristics and outcomes of patients with CA-GAD-ab. Result: Three patients with cerebellar ataxia, high GAD-ab titers and autoimmune endocrine disease were identified. Patients 1 and 2 had classic stiff person syndrome and insidious-onset cerebellar ataxia, while Patient 3 had pure cerebellar ataxia with subacute onset. Patients received intravenous immunoglobulin therapy with no response in Patients 1 and 3 and partial recovery in Patient 2. Conclusion: CA-GAD-ab is rare and its clinical presentation may hamper diagnosis. Clinicians should be able to recognize this potentially treatable autoimmune cerebellar ataxia.
\end{abstract}

Keywords: autoimmunity; cerebellar ataxia; diabetes mellitus.

\section{RESUMO}

A enzima ácido glutâmico descarboxilase (GAD), presente nos neurônios GABAérgicos e células beta do pâncreas, catalisa a conversão do ácido gama-aminobutírico (GABA). O cerebelo é altamente susceptível a mecanismos imunomediados, sendo a ataxia cerebelar associada ao anticorpo anti-GAD (CA-GAD) uma doença potencialmente tratável. Embora rara, sua frequência é crescente, com poucos casos descritos. Métodos: Estudo retrospectivo e descritivo avaliando características clínicas e desfechos da CA-GAD. Resultados: Três pacientes com CA-GAD, altos títulos de anti-GAD e doença endócrina autoimune foram identificados. Os pacientes 1 e 2 tinham síndrome da pessoa rígida em forma clássica e apresentação insidiosa da ataxia cerebelar, enquanto o paciente 3 tinha ataxia cerebelar pura e apresentação subaguda. Os pacientes 1 e 3 não melhoraram com imunoglobulina intravenosa e o paciente 2 teve recuperação parcial. Conclusão: A CA-GAD é rara e pode ter apresentação clínica desafiadora. Os médicos devem ser capazes de reconhecer essa forma potencialmente tratável de ataxia cerebelar autoimune.

Palavras-chave: autoimunidade; ataxia cerebelar; diabetes mellitus.

The spectrum of neurological syndromes associated with anti-glutamic acid decarboxylase antibodies (GAD-ab) is not well established and seems broader than previously believed ${ }^{1}$. The main neurological syndromes related to GAD-ab include stiff person syndrome (SPS), cerebellar ataxia, limbic encephalitis and epilepsy ${ }^{1,2,3}$. Glutamic acid decarboxylase is a cytoplasmic rate-limiting enzyme that catalyzes the conversion of gamma-aminobutyric

\footnotetext{
${ }^{1}$ Universidade Federal do Rio de Janeiro, Faculdade de Medicina, Hospital Universitário Clementino Fraga Filho, Serviço de Neurologia, Departamento de Clínica Médica, Rio de Janeiro RJ, Brasil;

${ }^{2}$ Universidade Federal do Rio de Janeiro, Faculdade de Medicina, Hospital Universitário Clementino Fraga Filho, Serviço de Nutrologia, Departamento de Clínica Médica, Rio de Janeiro RJ, Brasil;

${ }^{3}$ Universidade Federal do Rio de Janeiro, Faculdade de Medicina, Hospital Universitário Clementino Fraga Filho, Serviço de Endocrinologia, Departamento de Clínica Médica, Rio de Janeiro RJ, Brasil;

4 Universidade Federal do Estado do Rio de Janeiro, Faculdade de Medicina, Departamento de Neurologia, Rio de Janeiro, RJ, Brasil.

Correspondence: Marco Antônio Sales Dantas de Lima; Departamento de Neurologia, Hospital Universitário Clementino Fraga Filho/UFRJ; Rua Rodolpho Paulo Rocco, 255; 21941-913 Rio de Janeiro RJ, Brasil; E-mail:masdlima@gmail.com

Conflict of interest: There is no conflict of interest to declare.

Support: Rio de Janeiro State Foundation for the Support of Research (FAPERJ - Fundação de Amparo à Pesquisa do Estado do Rio de Janeiro).

Received 17 August 2016; Received in final form 05 November 2016; Accepted 05 December 2016.
} 
acid (GABA), an inhibitory neurotransmitter present in the central nervous system (CNS). It is found primarily in GABAergic neurons and in beta cells in the islets of Langerhans in the pancreas ${ }^{2,4}$. Glutamic acid decarboxylase is produced in two different isoforms with molecular weights of 65 and 67 kilodaltons (GAD65 and GAD67) encoded by two distinct genes; the main target for GAD-ab in neurological diseases is GAD65 $5^{1,2,3,4}$.

The cerebellum is an encephalic region highly susceptible to immune-mediated mechanisms. Cerebellar ataxia associated with anti-GAD-ab (CA-GAD-ab) is a rare and potentially treatable form of immune-mediated cerebellar ataxia, the detection of which is increasing $g^{5,6,7}$. The exact pathogenic role of GAD-ab in the cerebellar ataxias has yet to be fully understood; however, experimental data have suggested a direct excitotoxic effect of GAD-ab on Purkinje cells ${ }^{8}$. The presence of GAD-ab serves to confirm a possible autoimmune pathogenesis in the syndrome of cerebellar ataxia ${ }^{5,6,8}$

The objective of the current investigation was to evaluate a series of patients with cerebellar ataxia associated to anti-GAD-ab, comparing their clinical characteristics and outcomes. There are few descriptions of CA-GAD-ab in the literature; therefore, this information is useful to clinicians dealing with cases of immune-mediated cerebellar ataxias.

\section{METHODS}

This is a retrospective and descriptive study conducted by reviewing the clinical characteristics and outcomes of consecutive patients with CA-GAD-ab evaluated in the Neurology and Nutrology departments of the Clementino Fraga Filho Hospital of the Federal University of Rio de Janeiro between February 2013 and December 2015. Three CA-GAD-ab patients were selected retrospectively. Full consent was obtained from the all patients.

All CA-GAD-ab patients were submitted to a complete neurological evaluation; cerebrospinal fluid examination; a laboratory work-up that included measurement of onconeural antibodies, autoimmune encephalitis antibodies and serum levels of GAD-ab; genetic evaluation; and brain magnetic resonance imaging (MRI) scans. Brain MRI was performed in a 1.5T scanner Avanto (Siemens Medical Systems, Erlangen, Germany).

Diabetes was defined according to the criteria established by the American Diabetes Association ${ }^{9}$. Classic SPS was diagnosed in accordance with the Dalakas criteria ${ }^{10}$, with SPS variants being defined according to Barker et $\mathrm{al}^{11}$. Serum GAD-ab (GAD65-ab isoform) was measured with direct radiobinding assay, with the cut-off value for positivity being $\geq 1.0 \mathrm{Ui} / \mathrm{ml}$. High titers of GAD-ab were defined as $>100 \mathrm{Ui} / \mathrm{ml}$.

\section{RESULTS}

The three patients (two men and one woman) identified with CA-GAD-ab were between 43 and 57 years of age (mean: 49.3 years). The characteristics of the patients are shown in Table 1. Onset was either subacute or insidious. All patients had global cerebellar ataxia, although in Patient 2 the condition was predominantly axial. In Patients 1 and 2, classical SPS was associated with cerebellar ataxia, while Patient 3 had pure cerebellar ataxia. None of the patients had SPS variants, epilepsy or limbic encephalitis. Multidirectional nystagmus of CNS origin, and cerebellar dysarthria, were present in the patients. There were no findings of downbeat nystagmus, opsoclonus-myoclonus, ocular flutter, periodic alternating nystagmus or palatal myoclonus. None of the patients had a family history of cerebellar ataxia.

All three patients met the criteria for endocrine disease: latent autoimmune diabetes of adults in Patients 1 and 2 and autoimmune polyglandular syndrome type 2 in Patient 3. Two patients had a family history of endocrine disease. All the patients had high titers of GAD-ab (Patient 1: 102Ui/ml, Patient 2: $200 \mathrm{Ui} / \mathrm{ml}$, Patient 3: 200Ui/ml). Onconeural antibodies and autoimmune encephalitis antibodies, genetic evaluation, screenings for endocrine or organ specific autoimmunity were all normal (Table). Cerebrospinal fluid examination revealed the presence of anti-GAD in Patient 1 , while Patient 2 tested normal, and oligoclonal bands were found in Patient 3. Brain MRI scans revealed cerebellar atrophy only in Patient 3 (Figure).

Following intravenous immunoglobulin therapy (IVIG, $0.4 \mathrm{~g} / \mathrm{kg} /$ day for 5 days, followed by two cycles of single monthly doses $1 \mathrm{~g} / \mathrm{kg}$ ), there was no improvement in Patients 1 and 3 , and Patient 2 had a partial recovery.

\section{DISCUSSION}

Cerebellar ataxia associated with anti-GAD-ab is a rare disorder characterized by cerebellar ataxia concomitant in the presence of GAD-ab. The precise mechanism behind this condition remains unknown ${ }^{5,6,8,12}$. The disease affects mostly women in their sixth decade of life $e^{5,6,8,12}$. The present study evaluated three patients in their fifth and sixth decades of life, with two of these patients being male. As shown in this study, CA-GAD-ab may be either of insidious or subacute onset, with the disease tending to progress slowly over time ${ }^{5,6}$. All the patients reported here had global cerebellar ataxia; however, in Patient 2 the cerebellar ataxia was predominantly axial. Gait ataxia appears to be a severe and common problem in this condition ${ }^{1,5,6,13}$.

Few reports have been published on patients with CA-GAD-ab presenting with neuro-ophthalmic abnormalities $^{14,15,16,17,18,19}$. The three patients evaluated here had typical multidirectional nystagmus of CNS origin, although 
Table. Epidemiological and clinical characteristics of the analyzed patients.

\begin{tabular}{|c|c|c|c|}
\hline Variable & Patient 1 & Patient 2 & Patient 3 \\
\hline Age at onset/sex & 43 years/Male & 57 years/Female & 48 years/Male \\
\hline Type of onset & Insidious & Insidious & Subacute \\
\hline Type of cerebellar ataxia & Axial + appendicular & Axial + mild appendicular & Axial + appendicular \\
\hline Other neurological findings & $\begin{array}{l}\text { Nystagmus + severe } \\
\text { cerebellar dysarthria }\end{array}$ & $\begin{array}{l}\text { Nystagmus + moderate } \\
\text { cerebellar dysarthria }\end{array}$ & Nystagmus + mild cerebellar dysarthria \\
\hline Associated neurological disease & Classic SPS & Classic SPS & None \\
\hline Family history of cerebellar ataxia & No & No & No \\
\hline Associated endocrine disease & LADA & LADA & $\begin{array}{c}\text { APS } 2 \text { (LADA, Graves' disease and } \\
\text { Addison's disease) }\end{array}$ \\
\hline $\begin{array}{l}\text { Family history of endocrine } \\
\text { disease }\end{array}$ & Yes & Yes & No \\
\hline $\begin{array}{l}\text { Antineuronal / Endocrine } \\
\text { antibodies }\end{array}$ & $\begin{array}{c}\text { Anti-Yo, Anti-Hu, Anti-Ri, } \\
\text { Anti CV2, Anti-amphiphysin, } \\
\text { Anti-Ma1, Anti-Ma2: normal / } \\
\text { Anti-TPO, Anti-Tg, } \\
\text { TRAb, Anti-endomysial, } \\
\text { anti-transglutaminase: normal }\end{array}$ & $\begin{array}{c}\text { Anti-Yo, Anti-Hu, Anti-Ri, } \\
\text { Anti CV2, Anti-amphiphysin, } \\
\text { Anti-Ma1, Anti-Ma2: normal / } \\
\text { Anti-TPO, Anti-Tg, } \\
\text { TRAb, Anti-endomysial, } \\
\text { anti-transglutaminase: normal }\end{array}$ & $\begin{array}{l}\text { Anti-Yo, Anti-Hu, Anti-Ri, Anti } \\
\text { CV2, Anti-amphiphysin, Anti-Ma1, } \\
\text { Anti-Ma2: normal / } \\
\text { Anti-Tg, Anti-endomysial, } \\
\text { anti-transglutaminase: normal. } \\
\text { Anti-TPO and TRAb: positive. }\end{array}$ \\
\hline Anti-GAD & Positive (102 Ui/ml) & Positive (200 Ui/ml) & Positive (200 Ui/ml) \\
\hline CSF & $\begin{array}{c}\text { Anti-GAD } 82 \mathrm{Ui} / \mathrm{ml} \text {, otherwise } \\
\text { normal }\end{array}$ & Normal & Oligoclonal bands \\
\hline Brain MRI & Normal & Normal & Cerebellar atrophy \\
\hline \multirow{4}{*}{ Additional investigation } & $\begin{array}{c}\text { Chest, abdominal and pelvic } \\
\text { CT: normal }\end{array}$ & $\begin{array}{l}\text { Chest, abdominal and pelvic } \\
\text { CT: normal }\end{array}$ & \multirow{4}{*}{$\begin{array}{l}\text { Chest, abdominal and pelvic CT: normal. } \\
\text { Liver function tests, vitamin B12 and } \\
\text { folate levels: unremarkable }\end{array}$} \\
\hline & Thyroid US: normal. & Thyroid US: normal. & \\
\hline & $\begin{array}{l}\text { Liver, thyroid and adrenal } \\
\text { function tests, vitamin } \\
\text { B12 and folate levels: } \\
\text { unremarkable }\end{array}$ & $\begin{array}{c}\text { Breast and additional } \\
\text { gynecological examination: } \\
\text { normal. }\end{array}$ & \\
\hline & & $\begin{array}{l}\text { Liver, thyroid and adrenal } \\
\text { function tests, vitamin } \\
\text { B12 and folate levels: } \\
\text { unremarkable }\end{array}$ & \\
\hline Treatment & $\begin{array}{c}\text { Intravenous immunoglobulin } \\
\text { therapy }\end{array}$ & $\begin{array}{c}\text { Intravenous immunoglobulin } \\
\text { therapy }\end{array}$ & $\begin{array}{c}\text { Intravenous immunoglobulin } \\
\text { therapy }\end{array}$ \\
\hline Outcome & No improvement & Partial recovery & No improvement \\
\hline
\end{tabular}

SPS: stiff person syndrome; LADA: latent autoimmune diabetes of adults; APS 2: autoimmune polyglandular syndrome type 2; Anti-TPO: anti-thyroid peroxidase; Anti-Tg: anti-thyroglobulin; TRAb: thyrotropin receptor antibodies; CSF: cerebrospinal fluid; Anti-GAD: anti-glutamic acid decarboxylase antibodies; US: ultrasonography; CT: computed tomography; MRI: magnetic resonance imaging.
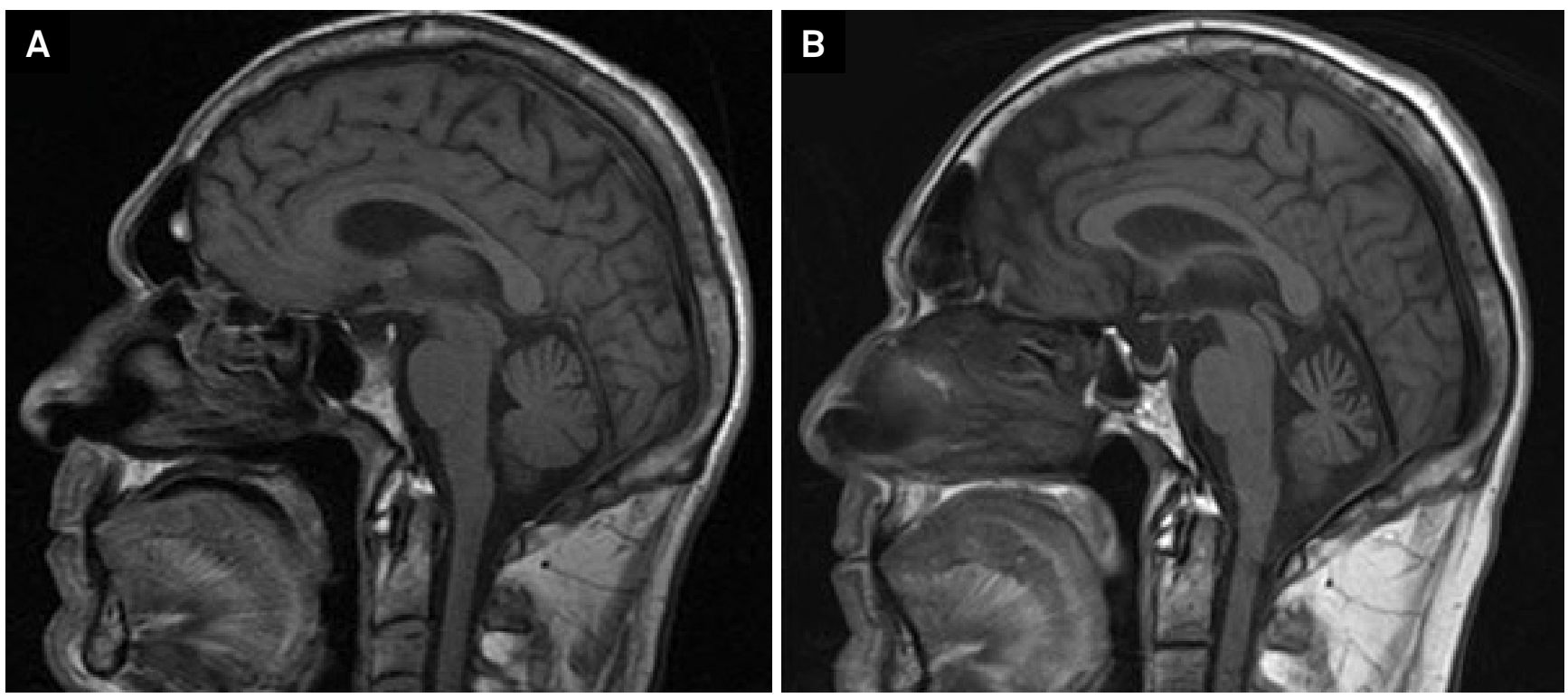

Figure. Patient 3. Sagittal T1-weighted image showing cerebellar atrophy. A) Initial brain MRI showing normal cerebellum; B) Brain MRI two years later showing prominent cerebellar atrophy. 
the spectrum of ocular manifestations in patients with CA-GAD-ab may be broader ${ }^{13,14,15,16,17}$. Recent studies have shown that spontaneous downbeat nystagmus can represent an important clue for a diagnosis of CA-GAD-ab ${ }^{18}$. It is probably related to abnormal GABAergic transmission at the cerebellum and its connections ${ }^{14,17,18}$.

Patients 1 and 2 have a more complex phenotype: classic SPS and cerebellar ataxia. Stiff person syndrome is a rare disorder characterized by muscle rigidity and episodic axial muscle spasms ${ }^{10,20}$. Continuous contraction of opposing muscles is caused by involuntary motor unit firing at rest and represents a clinical and electrophysiological hallmark of the disease ${ }^{10,20}$. It is also related to the autoimmune pathogenesis of the disease, and, although the antibody spectrum associated with SPS has broadened, GAD-ab and anti-amphiphysin remain those most typically associated with SPS $^{10,11,20,21}$. The association between SPS and CA-GAD-ab is even more unusual and creates additional challenges to diagnosis and treatment ${ }^{20,21,22,23,24,25,26}$. This overlap emphasizes a possible common mechanism, which is probably related to the widespread distribution of GAD throughout the $\mathrm{CNS}^{1,2,4,6}$.

A personal or familial history of other autoimmune diseases such as autoimmune diabetes mellitus, Addison's disease, hemolytic anemia or thyroiditis is commonly found in CA-GAD-ab ${ }^{6,22}$. All the patients reported here had an endocrine disorder: two had latent autoimmune diabetes of adults and one had autoimmune polyglandular syndrome type 2, also known as Schmidt syndrome, which is the most common of the immunoendocrinopathy syndromes characterized by the obligatory occurrence of autoimmune Addison's disease in combination with thyroid autoimmune disorders and/or autoimmune diabetes mellitus (type 1 diabetes mellitus or latent autoimmune diabetes of adults $)^{23}$. It should be emphasized, however, that even if there is no association with endocrinopathy, all patients with new onset of unexplained cerebellar ataxia should be investigated for treatable conditions $^{6}$ such as CA-GAD-ab.

Cerebrospinal fluid analysis may be normal or may show oligoclonal bands, mild pleocytosis and intrathecal synthesis of GAD-abs ${ }^{1,2,3}$. Brain MRI may also be normal or may reveal cerebellar atrophy ${ }^{1,2,3,5}$. For unknown reason, cerebellar atrophy is generally seen in patients with CA-GAD-ab without SPS ${ }^{5,6,24}$, and the patients in the present study are no exception.

The majority of cases of $\mathrm{CA}-\mathrm{GAD}$-ab reported in the literature involved high levels of GAD-ab ${ }^{1,6,25,26}$ but, even if the titers are low, the condition may be associated with an autoimmune mechanism ${ }^{13,27}$. A diagnosis of CA-GAD-ab is supported by the positivity for GAD-ab. The patients in this study had high titers, reinforcing the immune-mediated mechanism ${ }^{1,6}$.

Despite the absence of randomized controlled studies, immunotherapy regimens such as glucocorticoid, intravenous immunoglobulin, plasma exchange, and immunosuppressive agents in varying combinations are the mainstay of the treatment $t^{7,13,25,28,29,30}$. The response to treatment is variable, with complete remission being rare. However, there are a few reports that show favorable response ${ }^{13,30}$. No correlation has been found between serum GAD-ab titers and the severity of the disease, its phenotype or response to treatment $t^{5,7,25}$. The patients evaluated here underwent intravenous immunoglobulin therapy; however, partial recovery was achieved in Patient 2 alone, with Patients 1 and 3 showing no response to the treatment.

Recently, an increasing number of neurological disorders have been associated with GAD-ab ${ }^{1}$. Of the three patients with CA-GAD-ab described here, one had pure CA-GAD-ab, while the two remaining patients had a more complex phenotype, CA-GAG-ab plus SPS. The reason behind the susceptibility of the cerebellum to this form of immune-mediated disease is not fully understood, but is probably related to the distribution of GAD in Purkinje cells and a direct excitotoxic effect of GAD-ab ${ }^{6}$. Some autopsy studies have revealed a selective loss of Purkinje cells ${ }^{30}$. The potential pathogenic role of GAD-ab in neurological disorders remains to be clarified; however, plausible hypotheses include the inhibition of GABA synthesis and interference with exocytosis ${ }^{25}$. Further studies are required to understand the exact mechanisms of cerebellar ataxia in patients with $\mathrm{GAD}-\mathrm{Ab}$.

The full spectrum of CA-GAD-ab is vast and its clinical presentation can be challenging. Therefore, clinicians should be able to recognize this potentially treatable autoimmune condition when faced with any of the aforementioned neurological disorders.

\section{References}

1. Saiz A, Blanco Y, Sabater L, González F, Bataller L, Casamitjana R et al. Spectrum of neurological syndromes associated with glutamic acid decarboxylase antibodies: diagnostic clues for this association. Brain. 2008;131(10):2553-63. https://doi.org/10.1093/brain/awn183

2. Manto MU, Laute MA, Aguera M, Rogemond V, Pandolfo M, Honnorat J. Effects of anti-glutamic acid decarboxylase antibodies associated with neurological diseases. Ann Neurol. 2007;61(6):544-51. https://doi.org/10.1002/ana.21123

3. Vianello M, Tavolato B, Giometto B. Glutamic acid decarboxylase autoantibodies and neurological disorders. Neurol Sci. 2002;23(4):145-51. https://doi.org/10.1007/s100720200055
4. Fenalti G, Buckle AM. Structural biology of the GAD autoantigen. Autoimmun Rev. 2010;9(3):148-52. https://doi.org/10.1016/j.autrev.2009.05.003

5. Honnorat J, Saiz A, Giometto B, Vincent A, Brieva L, Andres C et al. Cerebellar ataxia with anti-glutamic acid decarboxylase antibodies: study of 14 patients. Arch Neurol. 2001;58(2):225-30. https://doi.org/10.1001/archneur.58.2.225

6. Mitoma H, Adhikari K, Aeschlimann D, Chattopadhyay P, Hadjivassiliou M, Hampe CS et al. Consensus Paper: Neuroimmune Mechanisms of Cerebellar Ataxias. Cerebellum 2016;15(2):213-232. https://doi.org/10.1007/s12311-015-0664-x 
7. Mitoma H, Hadjivassiliou M, Honnorat J. Guidelines for treatment of immune-mediated cerebellar ataxias. Cerebellum Ataxias. 2015;2(1):14. https://doi.org/10.1186/s40673-015-0034-y

8. Vianello M, Tavolato B, Armani M, Giometto B.

Cerebellar ataxia associated with anti-glutamic acid decarboxylase autoantibodies. Cerebellum. 2003;2(1):77-9. https://doi.org/10.1080/14734220309432

9. Association AD. Diagnosis and classification of diabetes mellitus. Diabetes Care. 2014;37 Suppl 1:S81-90. https://doi.org/10.2337/dc14-S08

10. Dalakas MC. Stiff person syndrome: advances in pathogenesis and therapeutic interventions. Curr Treat Options Neurol. 2009;11(2):102-10. https://doi.org/10.1007/s11940-009-0013-9

11. Barker RA, Revesz T, Thom M, Marsden CD, Brown P. Review of 23 patients affected by the stiff man syndrome: clinical subdivision into stiff trunk (man) syndrome, stiff limb syndrome, and progressive encephalomyelitis with rigidity. J Neurol Neurosurg Psychiatry. 1998;65(5):633-40. https://doi.org/10.1136/jnnp.65.5.633

12. Manto MU, Hampe CS, Rogemond V, Honnorat J. Respective implications of glutamate decarboxylase antibodies in stiff person syndrome and cerebellar ataxia. Orphanet J Rare Dis. 2011;6(1):3. https://doi.org/10.1186/1750-1172-6-3

13. Pedroso JL, Braga-Neto P, Dutra LA, Barsottini OG. Cerebellar ataxia associated to anti-glutamic acid decarboxylase autoantibody (anti-GAD): partial improvement with intravenous immunoglobulin therapy. Arq Neuropsiquiatr. 2011;69(6):993. https://doi.org/10.1590/S0004-282X2011000700030

14. Ances BM, Dalmau JO, Tsai J, Hasbani MJ, Galetta SL. Downbeating nystagmus and muscle spasms in a patient with glutamic-acid decarboxylase antibodies. Am J Ophthalmol. 2005;140(1):142-4. https://doi.org/10.1016/j.ajo.2004.12.052

15. Antonini G, Nemni R, Giubilei F, Gragnani F, Ceschin V, Morino S et al. Autoantibodies to glutamic acid decarboxylase in downbeat nystagmus. J Neurol Neurosurg Psychiatry. 2003;74(7):998-9. https://doi.org/10.1136/jnnp.74.7.998

16. Tilikete $C$, Vighetto A, Trouillas P, Honnorat J. Anti-GAD antibodies and periodic alternating nystagmus. Arch Neurol. 2005;62(8):1300-3. https://doi.org/10.1001/archneur.62.8.1300

17. Dubbioso R, Marcelli V, Manganelli F, Iodice R, Esposito M, Santoro L. Anti-GAD antibody ocular flutter: expanding the spectrum of autoimmune ocular motor disorders. J Neurol. 2013;260(10):2675-7. https://doi.org/10.1007/s00415-013-7110-0

18. Tilikete C, Vighetto A, Trouillas P, Honnorat J. Potential role of anti-GAD antibodies in abnormal eye movements. Ann N Y Acad Sci. 2005;1039(1):446-54. https://doi.org/10.1196/annals.1325.042

19. Vale TC, Pedroso JL, Alquéres RA, Dutra LA, Barsottini OG. Spontaneous downbeat nystagmus as a clue for the diagnosis of ataxia associated with anti-GAD antibodies. J Neurol Sci. 2015;359(1-2):21-3. https://doi.org/10.1016/j.jns.2015.10.024

20. Lorish TR, Thorsteinsson G, Howard FM Jr. Stiff-man syndrome updated. Mayo Clin Proc. 1989;64(6):629-36. https://doi.org/10.1016/S0025-6196(12)65339-7

21. Balint B, Bhatia KP. Stiff person syndrome and other immune-mediated movement disorders: new insights. Curr Opin Neurol. 2016;29(4):496-506. https://doi.org/10.1097/WC0.0000000000000351

22. Fernandes M, Munhoz RP, Carrilho PE, Arruda WO, Lorenzoni PJ, Scola RH et al. Neurological disorders associated with glutamic acid decarboxylase antibodies: a Brazilian series. Arq Neuropsiquiatr. 2012;70(9):657-61. https://doi.org/0.1590/S0004-282X2012000900002

23. Betterle C, Lazzarotto F, Presotto F. Autoimmune polyglandular syndrome Type 2: the tip of an iceberg? Clin Exp Immunol. 2004;137(2):225-33. https://doi.org/10.1111/j.1365-2249.2004.02561.x

24. Rakocevic G, Raju R, Semino-Mora C, Dalakas MC. Stiff person syndrome with cerebellar disease and high-titer anti-GAD antibodies. Neurology. 2006;67(6):1068-70. https://doi.org/10.1212/01.wnl.0000237558.83349.d0

25. Ariño H, Gresa-Arribas N, Blanco Y, Martínez-Hernández E, Sabater L, Petit-Pedrol M et al. Cerebellar ataxia and glutamic acid decarboxylase antibodies: immunologic profile and long-term effect of immunotherapy. JAMA Neurol. 2014;71(8):1009-16. https://doi.org/10.1001/jamaneurol.2014.1011

26. Gordon CR, Zivotofsky AZ, Siman-Tov T, Gadoth N, Dalakas MC. Stiff person syndrome with cerebellar disease and high-titer anti-GAD antibodies. Neurology. 2007;68(14):1161. https://doi.org/10.1212/01.wnl.0000261162.61360.a2

27. Nanri K, Niwa H, Mitoma H, Takei A, Ikeda J, Harada Tet al. Low-titer anti-GAD-antibody-positive cerebellar ataxia. Cerebellum. 2013;12(2):171-5. https://doi.org/10.1007/s12311-012-0411-5

28. Nanri K, Okita M, Takeguchi M, Taguchi T, Ishiko T, Saito H et al. Intravenous immunoglobulin therapy for autoantibody-positive cerebellar ataxia. Intern Med.. 2009;48(10):783-90. https://doi.org/10.2169/internalmedicine.48.1802

29. Dogan VB. An anti-GAD autoantibody-associated cerebellar syndrome case: a curable cause of ataxia. Neurol Sci. 2015;36(10):1929-31. https://doi.org/10.1007/s10072-015-2280-4

30. Ishida K, Mitoma H, Wada Y, Oka T, Shibahara J, Saito Y et al. Selective loss of Purkinje cells in a patient with anti-glutamic acid decarboxylase antibody-associated cerebellar ataxia. J Neurol Neurosurg Psychiatry. 2007;78(2):190-2. https://doi.org/10.1136/jnnp.2006.091116 